\title{
Buprestis splendens (Fabricius, I774) (Coleoptera Buprestidae) on the Calabrian side of the "Parco Nazionale del Pollino" (Calabria, Italy): distribution and ecological observation
}

\author{
Sandro Piazzini', Matteo Tamburini', Francesca Martini² \& Leonardo Favilli' \\ ${ }^{1}$ Department of Physical Sciences, Earth and Environment, University of Siena, via P.A. Mattioli 4 I-53100 Siena (Italy) \\ ${ }^{2}$ D.R.E.AM Italia, Via Garibaldi, 3 -52015 Pratovecchio Stia (AR) \\ ${ }^{*}$ Corresponding author, e-mail: piazzini5@unisi.it
}

\begin{abstract}
Buprestis splendens (Fabricius, 1774) (Coleoptera Buprestidae) is a rare European chorotype species, threatened throughout its distribution by global climate change, forest fires and the capture of specimens by collectors. To date, in Italy, its presence was only known in a few areas on the Lucanian side of the massif of Pollino. This report records the first, reliable sightings of its presence on the Calabrian side of the Pollino and in the mountains of Orsomarso. It also makes observations on its environment and the factors that put its survival at risk.
\end{abstract}

KEY WORDS

Coleoptera; Buprestis splendens; distribution; Pollino massif; Orsomarso mountains; Calabria.

Received 21.04.2020; accepted 10.08.2020; published online 30.09.2020

\section{INTRODUCTION}

Buprestis splendens (Fabricius, 1774) (Coleoptera Buprestidae) is a rare European chorotype species, known in just a few sites in Russia, Finland, Poland, Albania, Bosnia-Erzegovinia, Greece, Italy and Spain. Information on its environment and biology is scarce. It favours fresh climates and is linked to ancient conifers, in particular the Scotts Pine (Pinus sylvestris Linnaeus), the Black Pine (Pinus nigra Arnold) and the Bosnian Pine (Pinus heldreichii Christ subsp. leucodermis Antoine). The female lays her eggs on the dead trees and the larvae feed on the rotting wood. In the southern part of its range, the period of maximum activity by adults seems to coincide with the month of August (Mason et al., 2010; Trizzino et al., 2013; Curletti et al., 2016). In Italy, it is a strictly mountain species, ranging as far as $2000 \mathrm{~m}$ asl around the Bosnian Pine. There are few indications of its presence, all limited to the Lucanian side of the Massiccio del Pollino (Gobbi, 1973; Izzillo, 1989; Curletti, 1994; 2007). It is currently one the coleopteran species most at risk in Europe, threatened by the illegal felling of old trees, from forest fires and from the sale of specimens to collectors. For these reasons, $B$. splendens is included in paragraphs II and IV of the Directive 92/437/CEE (attached). It is considered 'Endangered' at global level (Mason et al., 2010), 'Vulnerable' in the Mediterranean region (Garcia et al., 2018) and 'Endangered' in Italy (Rondinini et al., 2013).

In 2018 and 2019, in a study on species of insects of interest to the European community present in the areas of Rete Natura 2000, one of our team (S. Piazzini) conducted accurate research on the presence and distribution of $B$. splendens on the $\mathrm{Ca}$ labrian side of the National Park of Pollino. The study was promoted and approved by the Depart- 
ment of the environment and Territory of the Region of Calabria and the Institution of the National Park of Pollino.

\section{MATERIAL AND METHODS}

\section{Study area}

The Calabrian side of the National Park of Pollino stretches over 103,915 hectares of the total protected area of 192,565 hectares, part of which is also in Basilicata. It is a vast area, entirely within the province of Cosenza, extending from the top of the valley of the river Lao (Laino Borgo) in the north and the Ciagola range of mountains, as far as the crest of the Pollino range, in the south including all the Orsomarso mountains between Orsomarso and Serra La Vriglia in Belvedere Marittimo. Research in relation to $B$. splendens is concentrated to areas of formations of Bosnian pines at higher altitudes. These are Monte Pollino (2248 m), Serra Dolcedorme (2267 m), Serra delle Ciavole and Monte Manfriana (Pollino range), La Montea (1827 m) and Monte La Caccia (1760 m) (Orsomarso mountains).

In this area, geologically, the substrate is almost entirely calcareous and relates to three carbonate units: Lungro-Verbicaro, Pollino-Ciagola and Cetraro (Iannace et al., 2005; 2007). The vegetation comprises woodland - predominantly beech (Fagus sylvatica Linnaeus); mesophylic beech (from 1300-1400m), microthermal beech (up to $2000 \mathrm{~m}$ ). Above this level there are mesophyilic mountain pastures and high mountain xeric grasslands.

Of particular interest are the formations of conifers at high altitude, dominated by Bosnian pines, (Pinus heldreichii). These are found particularly on the crests and the steepest slopes which have rocky substrates (Avena \& Bruno, 1975; Gargano et al. 2012). Considering the ecological requirements of Buprestis splendens, research has been carried out exclusively at the highest points of the National Park where these coniferous trees grow; Monte Pollino (2248 m), Serra Dolcedorme (2267 m), Serra delle Ciavole and Monte Manfriana, in the Pollino range; La Montea (1827 m) and Monte La Caccia (1760 m), in the Orsomarso mountains.

\section{Methods of sampling}

Eleven areas have been identified where there are adult dead or decaying trees potentially providing suitable habitat for $B$. splendens. Each of these areas was visited on at least four occasions between July and September 2018 and June and August 2019. Using an experimental method suggested by Curletti et al. (2016) (not developed or tested prior to this study), the species was sampled through direct observation of exit holes on dead or decaying Bosnian pines. This method was adapted in the field. Initially, surveys were conducted in sample areas of around $5000 \mathrm{sqm}$ in which there were at least ten dead or decaying trees showing exit holes made by $B$. splendens. In each area at least three trees were marked by a cairn built at the base, noting the exact position using GPS coordinates. The three specimens showed at least 150 flickering holes, some of which were recent and recognisable by the light colour inside. The holes were circled using a coloured, indelible pen. The marking was done twice - once at the end of summer 2018 and once at the beginning of summer 2019 as in some cases the marking had weathered over the winter. It is advisable to leave the marking in May and the first half of June.

\section{RESULTS AND DISCUSSIONS}

The presence of the species has been confirmed in six of the eleven areas visited (Table 1).

1. The southern ridge of the Serra delle Ciavole (SIC IT310013 Serra of the Ciavole-Serra, Crispo) at $1900 \mathrm{~m}$ asl and at $2040 \mathrm{~m}$ asl.

2. Two sites on the southern range of the Serra Dolcedorme (SIC IT9310003 Pollinello-Dolcedorme).

3. In proximity of the Passo del Vascello at $2050 \mathrm{~m}$ and at $1980 \mathrm{~m}$ on the southern side.

4. Monte Pollino on rock formations west of the Pollinello valley at $1970 \mathrm{~m}$.

5. Orsomarso mountains on the eastern crest of La Montea, at $1750 \mathrm{~m}$.

The above include the first confirmed sightings in Calabria and the first ever in the Orsomarso mountains.

The species has not been detected on Monte Manfriana or Monte La Caccia despite the habitat 


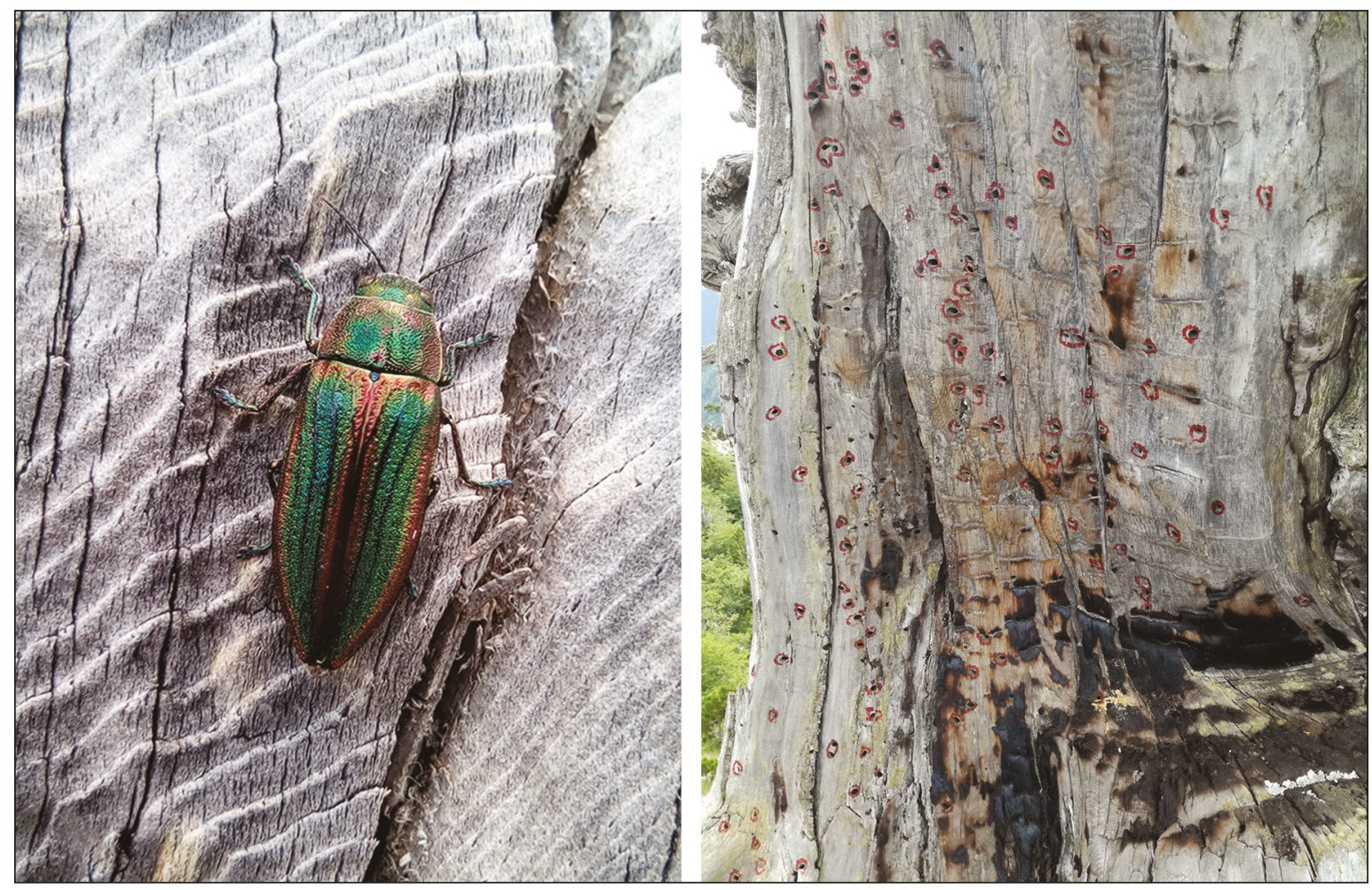

Figure 1 (left). Buprestis splendens (Fabricius, 1774), Serra delle Ciavole, 8.08.18 (photo M. Di Luca). Figure 2 (right). Marking of exit holes with indelible pen (photo S. Piazzini)

being considered appropriate. On Monte Manfriana, a number of dead trees have been identified on which there are exit holes relating to B. splendens but it has not been possible to verify its presence.

That does not exclude the possibility that the species is present and may be discovered as research continues. On the other hand, it is probable that on Monte La Caccia, B.splendens has recently become extinct due to an extensive forest fire a few years ago and an increase of temperatures due to climate change making the environment less favourable for the species. Indeed $B$. splendens is linked to mountains and cooler climates to the south of its range of distribution (Trizzino et al., 2013).

An accurate evaluation of the population is only possible through studies carried out over a number of years (at least five). From current data indicating the number of specimens discovered and the number of new exit holes observed, we can confirm that in the areas investigated, the species is present in metapopulations, each made up of tens of specimens.
The areas where $B$. splendens is found are all at high altitudes, ranging from $1750 \mathrm{~m}$ to $2100 \mathrm{~m}$. These areas are predominately rocky and populated by formations well structured of Bosnian pines with contemporary presence of ancient, dead and decaying trees, standing and fallen. Observation of exit holes and specimens indicates that the species tends to colonise mostly the basal and decaying parts of older trees and broken trunks of pines both standing and fallen. Contrary to Koch's belief (1989), it appears to avoid wood that is excessively rotten and decomposed. B. splendens also appears to show a certain preference for trees, or parts of trees that have been struck by lightening and partially burnt. According to available data, adult emerging seems to happen from the end of June in lower areas and throughout July at higher levels. In the areas investigated, what most threatens the survival of $B$. splendens are forest fires, collecting of specimens and global climate change. Indeed the species was detected only at very high altitudes (above $1700 \mathrm{~m}$ ), while in the sites monitored at lower altitudes it was not ascertained and probably extinct in 


\begin{tabular}{|c|c|c|c|c|}
\hline Locality & $\begin{array}{l}\text { Geographic } \\
\text { coordinates }\end{array}$ & Altitude & Date & Evidence \\
\hline \multirow[t]{8}{*}{ Serra delle Ciavole (Cerchiara di Calabria, CS) } & $39^{\circ} 54^{\prime} \mathrm{N}-16^{\circ} 13^{\prime} \mathrm{E}$ & $1900 \mathrm{~m}$ & 27.07 .18 & \\
\hline & & & $\begin{array}{l}1 \text { specimen } \\
\text { dead }\end{array}$ & \\
\hline & & & 08.08 .18 & 1 female \\
\hline & & & 13.08 .18 & \\
\hline & & & 06.09 .18 & \\
\hline & & & 14.06 .19 & \\
\hline & & & 09.07 .19 & \\
\hline & & & 27.07 .19 & 1 new exit hole \\
\hline \multirow{7}{*}{ Serra delle Ciavole (Cerchiara di Calabria, CS) } & $39^{\circ} 54^{\prime} \mathrm{N}-16^{\circ} 13^{\prime} \mathrm{E}$ & $2040 \mathrm{~m}$ & 27.07 .18 & \\
\hline & & & 08.08 .18 & \\
\hline & & & 13.08 .18 & \\
\hline & & & 06.09 .18 & \\
\hline & & & 14.06 .19 & \\
\hline & & & 09.07 .19 & \\
\hline & & & 27.07 .19 & 2 new exit holes \\
\hline \multirow[t]{6}{*}{ Serra Dolcedorme (Castrovillari, CS) } & $39^{\circ} 53^{\prime} \mathrm{N}-16^{\circ} 13^{\prime} \mathrm{E}$ & $2050 \mathrm{~m}$ & 27.07 .18 & \\
\hline & & & 08.08 .18 & $\begin{array}{l}1 \text { female }+2 \text { new exit } \\
\text { hole with fresh sawdust }\end{array}$ \\
\hline & & & 13.08 .18 & \\
\hline & & & 14.06 .19 & \\
\hline & & & 27.07 .19 & \\
\hline & & & 13.08 .19 & 1 new exit hole \\
\hline \multirow[t]{6}{*}{ Serra Dolcedorme (Castrovillari, CS) } & $39^{\circ} 53^{\prime} \mathrm{N}-16^{\circ} 13^{\prime} \mathrm{E}$ & $1980 \mathrm{~m}$ & 27.07 .18 & \\
\hline & & & 08.08 .18 & \\
\hline & & & 13.08 .18 & \\
\hline & & & 14.06 .19 & \\
\hline & & & 27.07 .19 & 1 new exit hole \\
\hline & & & 13.08 .19 & \\
\hline \multirow[t]{4}{*}{ Monte Pollino (Castrovillari, CS) } & $39^{\circ} 53^{\prime} \mathrm{N}-16^{\circ} 11^{\prime} \mathrm{E}$ & $1950 \mathrm{~m}$ & 26.08 .18 & \\
\hline & & & 14.06 .19 & \\
\hline & & & 08.07 .19 & \\
\hline & & & 24.07 .19 & \\
\hline \multirow[t]{4}{*}{ Monte Pollino (Morano Calabro, CS) } & $39^{\circ} 54^{\prime} \mathrm{N}-16^{\circ} 11^{\prime} \mathrm{E}$ & $1970 \mathrm{~m}$ & 26.08 .18 & \\
\hline & & & 14.06 .19 & \\
\hline & & & 08.07 .19 & \\
\hline & & & 24.07 .19 & 1 exit hole \\
\hline \multirow[t]{4}{*}{ Monte Manfriana (Frascineto, CS) } & $39^{\circ} 52^{\prime} \mathrm{N}-16^{\circ} 14^{\prime} \mathrm{E}$ & $1945 \mathrm{~m}$ & 26.06 .19 & \\
\hline & & & 13.07 .19 & \\
\hline & & & 27.07 .19 & \\
\hline & & & 10.08 .19 & \\
\hline \multirow[t]{6}{*}{ La Montea (Mottafollone, CS) } & $39^{\circ} 39^{\prime} \mathrm{N}-15^{\circ} 57^{\prime} \mathrm{E}$ & $1685 \mathrm{~m}$ & 25.07 .18 & \\
\hline & & & 11.08 .18 & \\
\hline & & & 23.08 .18 & \\
\hline & & & 12.06 .19 & \\
\hline & & & 14.07 .19 & \\
\hline & & & 11.08 .19 & \\
\hline
\end{tabular}




\begin{tabular}{|c|c|c|c|c|}
\hline \multirow[t]{6}{*}{ Montea, cresta sudest (Mottafollone, CS) } & $39^{\circ} 39^{\prime} \mathrm{N}-15^{\circ} 56^{\prime} \mathrm{E}$ & $1750 \mathrm{~m}$ & 25.07 .18 & \\
\hline & & & 11.08 .18 & \\
\hline & & & 23.08 .18 & \\
\hline & & & 12.06 .19 & \\
\hline & & & 14.07 .19 & 1 new exit hole \\
\hline & & & 11.08 .19 & \\
\hline \multirow[t]{4}{*}{ Monte La Caccia (Belvedere Marittimo, CS) } & $39^{\circ} 39^{\prime} \mathrm{N}-15^{\circ} 55^{\prime} \mathrm{E}$ & $1550 \mathrm{~m}$ & 23.08 .18 & \\
\hline & & & 12.06 .19 & \\
\hline & & & 14.07 .19 & \\
\hline & & & 07.08 .19 & \\
\hline \multirow[t]{4}{*}{ Monte La Caccia (Belvedere Marittimo, CS) } & $39^{\circ} 39^{\prime} \mathrm{N}-15^{\circ} 55^{\prime} \mathrm{E}$ & $1385 \mathrm{~m}$ & 23.08 .18 & \\
\hline & & & 12.06 .19 & \\
\hline & & & 14.07 .19 & \\
\hline & & & 07.08 .19 & \\
\hline
\end{tabular}

Table 1. Examined localities with suitable habitats and evidence of the species. For conservation reasons, the exact location of discovery sites is not indicated, and the seconds are omitted in the geographical coordinates.

recent times precisely because of global warming (as demonstrated in Spain) (Hernandez-Manrique et al., 2013).

Taking the above into account it is clear that the conservation of B. splendens in Italy is problematic. Considering the difficulty, if not impossibility of taking actions that would effectively mitigate the negative effects of climate change, what could and should be done to conserve the populations would be to increase controls over the entirety of the $\mathrm{Na}$ tional Park, to prevent fires and stop the collection of insects. It would be constructive to extend the research to the Lucanian side of the protected area. With more precise information of the distribution and size of the population of this species, further interventions towards its conservation could be proposed.

\section{ACKNOWLEDGEMENTS}

Our thanks go to the Territorial Department of the Region of Calabria and the National Park of Pollino, in particular to Vittoria Marchianò and Francesco Rotondaro who have supported our research; to Nevio Agostini, Massimo Bartolini, Rossana Bruschi, Alice Crescioli, Lorenzo Foggi, Sarah Gonnelli, Alessandro Pace, Francesco Pinzauti and Iuri Sbrilli all of whom have taken part in the research in the field; to Sophie Chamberlain for the English translation of the text.

\section{REFERENCES}

Avena G.C. \& Bruno F., 1975. Lineamenti della vegetazione del massiccio del Pollino, Appennino calabrolucano. Notiziario Fitosociologico, 10: 131-153.

Curletti G., 1994. I Buprestidi d'Italia. Museo Civico di Scienze Naturali di Brescia, Monografie di Natura Bresciana, 19: 318 pp.

Curletti G., 2007. Buprestis splendens. In: Ruffo S. \& Stoch F. (a cura di), Ckmap: Checklist and distribution of the italian fauna. Ministero dell'Ambiente Servizio di Conservazione della Natura. CD Rom.

Curletti G., Rovelli V., Bologna M.A. \& Zapparoli M., 2016. Buprestis splendens (Fabricius, 1774) (Bupreste splendida). 66-67 pp. In: Stoch F.\& Genovesi P., 2016. Manuali per il monitoraggio di specie e habitat di interesse comunitario (Direttiva 92/43/CEE) in Italia: specie animali. ISPRA, Serie Manuali e linee guida, 141/2016, 66-67.

García N., Numa C., Bartolozzi L., Brustel H., Buse J., Norbiato M., Recalde J.I., Zapata J.L., Dodelin B., Alcázar E., Barrios V., Verdugo A., Audisio P., Micó E., Otero J. C., Bahillo P., Viñolas A., Valladares L., Méndez M., El Antry S. \& Galante E., 2018. The conservation status and distribution of Mediterranean saproxylic beetles. IUCN, Malaga, xii +58 pp. https://doi.org/10.2305/IUCN.CH.2018.RA.3.en

Gargano D., Mingozzi A., Massolo A., Rinaldo S. \& Bernardo L., 2012. Patterns of vegetation cover/dynamics in a protected Mediterranean mountain area: influence of the ecological context and protection policy. Plant Biosystems, 146: 9-8. https://doi.org/ 10.1080/11263504.2011.641689

Gobbi G., 1973. I Buprestidi dell'Appennino Lucano 
(Coleoptera Buprestidae). Bollettino dell'Associazione romana di Entomologia, 26: 33-65.

Hernandez-Manrique O.L., Sanchez-Fernandez D., Numa C., Galante E., Verdu J.R. \& Lobo J.M., 2013. Extinction trends of threatened invertebrates in peninsular Spain. Journal of Insect Conservation, 17: 235-244. https://doi.org/10.1007/s10841-012-9502-3

Iannace A., Garcia-Tortosa F.J. \& Vitale S., 2005. Triassic metasedimentary successions across the boundary between the southern Apennines and the Calabrian Arc (northern Calabria, Italy). Geological Journal, 40: 155-171. https://doi.org/10.1002/gj.1001

Iannace A., Vitale S., D’Errico M., Mazzoli S., Di Staso A., Macaione E., Messina A., Reddy S.M., Somma R., Zamparelli V., Zattin M. \& Bonardi G., 2007. The carbonate tectonic units of northern Calabria (Italy): a record of Apulian palaeomargin evolution and Miocene convergence, continental crust subduction, and exhumation of HP LT rocks. Journal of the Geological Society, 164: 1165-1186. https://doi.org/10. 1144/0016-76492007-017

Izzillo F., 1989. Coleoptera, Buprestidae. Buprestis
(Cypriacis) splendens Fabricius, 1793. Bollettino dell'Associazione Romana di Entomologia, 43: 73.

Koch K., 1989. Die kafer mitteleuropas: okologie band 2. Goecke \& Evers, Krefeld, 382 pp.

Mason F., Campanaro A., Horák, J., Istrate P., Munteanu N., Büche B., Tezcan S., Méndez M. \& Dodelin B., 2010. Buprestis splendens. The IUCN Red List of Threatened Species 2010: e.T3334A9778017. Available from https://dx.doi.org/10. 2305/IUCN.UK. 20101.RLTS.T3334A9778017.en. Accessed 2020/2/11.

Rondinini C., Battistoni A., Peronace V. \& Teofili C., 2013. Buprestis splendens ssp. splendens. Liste Rosse Italiane. Available from http://www.iucn.it/ scheda.php?id=1463382073 Accessed 2020/2/11.

Trizzino M., Audisio P., Bisi F., Bottacci A., Campanaro A., Carpaneto G.M., Chiari S., Hardersen S., Mason F., Nardi G., Preatoni D.G., Vigna Taglianti A., Zauli A., Zilli A. \& Cerretti P. (Eds.), 2013. Gli artropodi italiani in Direttiva Habitat: biologia, ecologia, riconoscimento e monitoraggio. Quaderni Conservazione Habitat, 7. CFS-CNBFVR, Centro Nazionale Biodiversita Forestale. Cierre Grafica, Sommacampagna, Verona, 256 pp. 